\title{
観光開発の地域的インパクトに関する考察
}

一三重県奥志摩地域の事例—

淡野明彦

\section{1. 研究テーマの設定}

地域経済の発展には，産業誘致策と地場産業の育 成との二つの方向が考えられ，従来はその産業対象 として工業が主力であった。しかし，近年における 観光活動の活発化は, 観光を有望な業種として注目 させることとなった。観光開発のパイオニア的役割 を果してきた大手私鉄資本による開発も，点から面 へと大規模に展開しているのをはじめ，他業種資本 による観光市場への新規参入も盛んである。地方自 治体サイドにおいては，直営による観光施設の設置 や，地元の小規模な観光資本への資金融資や土地の 斡旋等による助成により，観光開発を促進する方策 がとられる。しかし，大規模な観光開発のためには， 自治体による莫大な資金の調達難, 地元でのノウ八 ウの不足といった障害のため，外来の大資本の導入 によって，観光開発の実現を図ろうとする場合が多 い。いずれの場合にも, 地域の産業振興による住民 の雇用機会の増大と安定，個人所得の増大および財 政の改善がねらいである。ことにこれまで自然条 件（立地条件）の不利さのため，工業開発とは疎遠 で,このため雇用機会の不足・低所得・人口流出に 悩んできた自治体にとって，観光開発は地域の自然

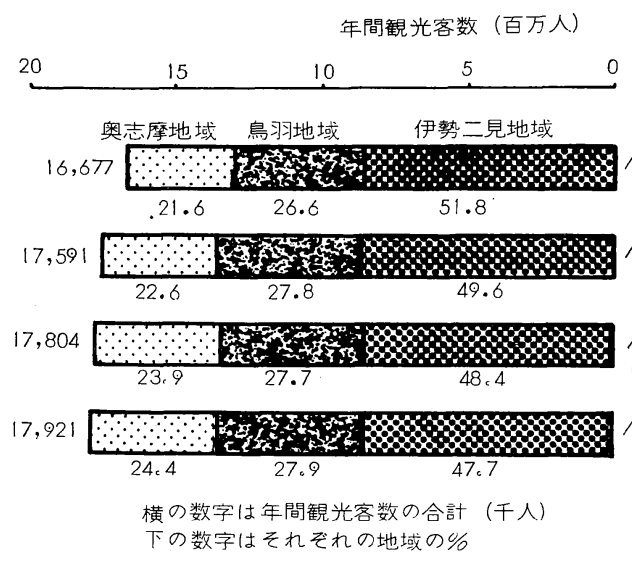

条件を生かした産業振興策として期待されている。 筆者はさきに埼玉県秩父地方において一大手私鉄 資本が展開した観光開発による地域的インパクトを， 雇用と土地利用の二つの面がらミクロスケールで考 察した（淡野明彦，1974）。集落レベルでの考察 であったため，観光開発が市町村レベルに及ぼした 影響については論述が至らなかった。その後, 菊地 一郎と筆者 ( 1979 ) は, 観光開発の地域的インパ クトを市町村レベルでとらえる試みを行った。伊勢 志摩 (国立公園 ) 地域を研究対象地域とし, 観光開 発の展開過程をふまえ, 伊勢志摩地域内の市町村 の観光開発の地域的インパクトの大要を明らかにし た。その結果，市町村の経済規模と観光開発との相 関が認められ，経済規模の小さなところほど観光開 発が盛んで，観光開発の時期的に新しいところほど 経済規模が小さくなっていることが明らかとなり， 観光開発が地域経済振興へのキーとして位置づけら れていることがうかがえた。しかし，観光開発が人 口流出の阻止と当該地域住民の所得の向上のそれぞ れに及ぼす効果については考察が進まなかった。

本稿は筆者らの前記論文での考察をより具体的に, かつ残された点の解明にも向けて，観光開発の地域 的インパクトを雇用・所得・財政の面から考察した。

年間推定消費額（10億円）

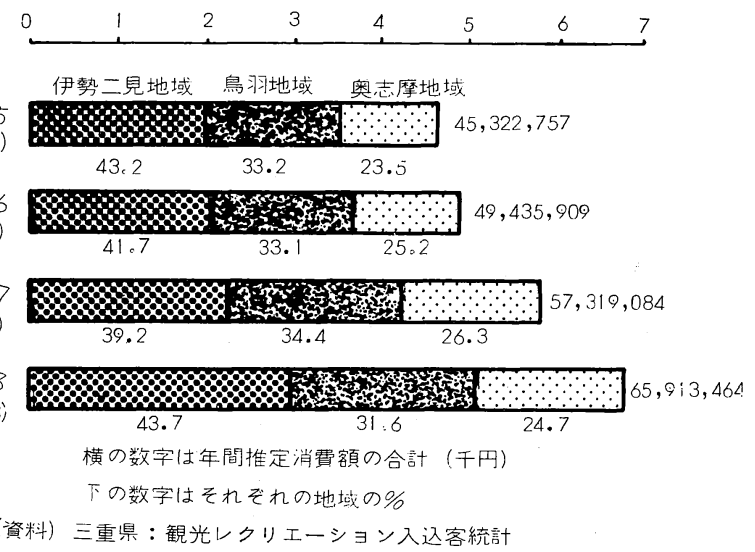

図 1 伊勢志摩における地域別年間観光客数および年間推定消費額 
考察を詳細にする必要のため, 研究対象地域を伊勢 志摩地域のうち奥志摩地域 ${ }^{1)}$ に絞った。

\section{2. 奥志摩地域における観光の概況}

\section{1 ) 観光の動向}

伊勢志摩は温暖な気候と海洋美に恵まれたわが国 有数の観光地として著名で，年間観光客数は 1,792 万人（ 1978 年,三重県調查 )で，これは同年の三重 県内観光客総数の約 $40 \%$ に当たり,第 2 位の水郷県 立公園の $15 \%$ ，第 3 位の鈴鹿国定公園の $9 \%$ を大 きく引き離している。観光客による推定消費額にお いても，伊勢志摩は総額 659 億円で三重県総額の $57 \%$ 占めており，三重県観光産業における伊勢 志摩の地位は卓越している。伊勢志摩は観光地とし ての性格とその開発の経緯から，伊勢二見地域・鳥 羽地域・奥志摩地域の 3 地域に区分することができ る(浜口誠, 1975 , 菊地・淡野，1979）。最近 4 年閒における 3 地域への観光客数と観光客による推 定消費額の動向をみると（図 1 )，観光客数は三地 域の比率に大きな変化はないが，奥志摩地域におけ る観光客の増加が三地域の内では最も多く, 奥志摩 地域の鳥羽地域に比肩する地位への上昇がみられる。 推定消費額では，1978（昭和 53 ）年においてやや 乱れがあるが，観光客数と同じ傾向がみられ，推定 消費額の面でも奥志摩地域の観光地としての地位の 上昇がみられる。奥志摩地域における町別の観光客

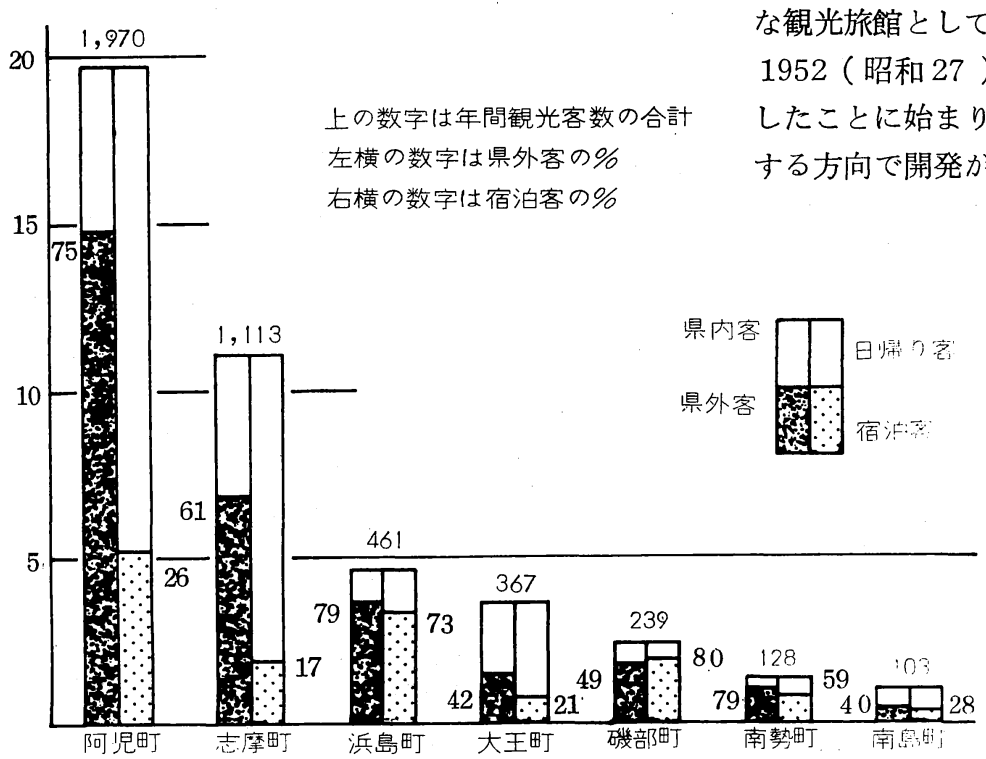

(資料)図儿回し
数および推定消費額について，1978（昭和 53 ) 年 の実績でみると（図 2，3），阿児町が観光客数・ 推定消費額ともに最も高く，これに観光客数では志 摩町・浜島町・大王町が続くが，推定消費額では浜 島町・志摩町 一磯部町と続く。観光客の客質による 内訳（図 2 ）をみると，阿児町・浜島町・南勢町で 県外客の占める比率が高く，また浜島町・磯部町で は宿泊客の比率が高い。奥志摩地域では町別による 観光客数だけでなく，客質における差異も顕著であ る。

\section{2 ）観光施設および交通機関}

観光開発において，観光客を誘致するための宿泊 施設・レクリエーション施設の設置，交通機関の整 備は不可欠なものである。奥志摩地域において記録 的に把握できる観光開発の実績は，1927（昭和 2) 年に真珠湾交通 ${ }^{2)}$ による英盧湾遊覧船の開業がみら れるが，本格的な開発は1946（昭和 21 )年の伊勢 志摩国立公園指定以後において展開された。その端 緒は，阿児町賢島（神明）地区と浜島町目戸山地区 においてみられた。阿児町賢島地区の開発は, 1949 （昭和 $24 ）$ 年に三重県が近鉄資本の導入によって, 観光拠点としてのホテルの建設に着手し，その後近 鉄資本によるホテル・旅館の増設が続いた。浜島町 目戸山地区の開発は，かつての避難港としての特性 から発達した小規模な歓楽地区を，町当局が近代的 な観光旅館として発展させるための誘導策として， 1952（昭和 27 ）年に観光開発土地整備事業を開始 したことに始まり，地元の小規模な観光資本を育成 する方向で開発が進められ，観光旅館街の形成をみ

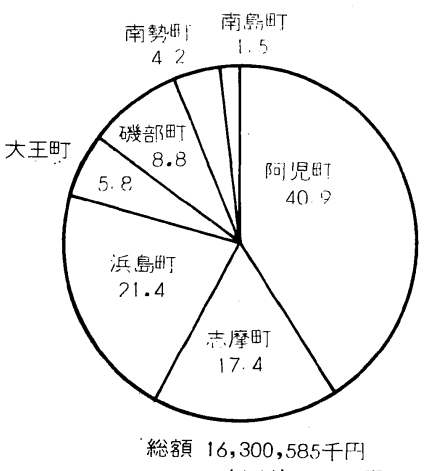

(資料)図に问に

図 3 奥志摩地域の町別年間推定

図 2 奥志摩地域の町別観光客数（1978年） 消費額（1978年） 


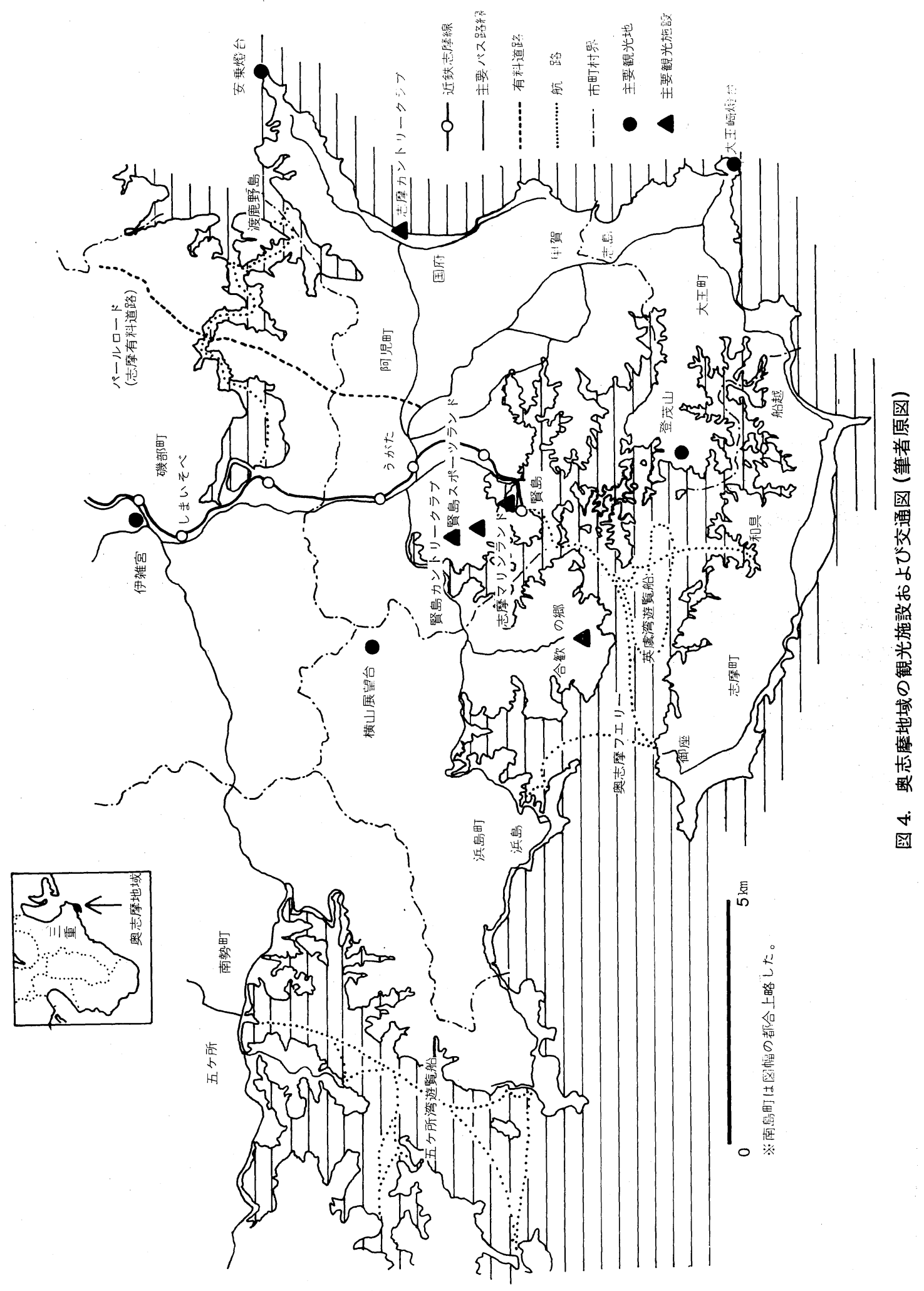


た。このように奥志摩地域の二大観光拠点である阿 児町と浜島町とでは，宿泊施設の整備においてその 開発主体が対照的であった。しかし，浜島町に 1968 (昭和 43 )年に日本楽器製造（ヤマ八）による大規

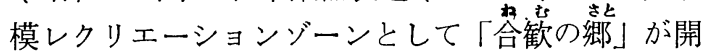
業し, 外来の大手資本の参入をみた。奥志摩地域の 町別の宿泊施設数をみると（表 1 ），日本観光旅館 連盟 (日観連) 加盟旅館の阿児町・浜島町への集中 がみられる。阿児町では政府登録ホテル。日観連加 盟旅館によって供給される室数の $73 \% か ゙$ 近鉄系列 によるものである。志摩町・大王町。南勢町では民 宿 $^{3)}$ が宿泊施設の主体となっており，夏季の海水浴 客を対象とした家族経営による零細なものが多い。 宿泊施設以外の観光施設においても，阿児町が傑出 しており，2 カ所のゴルフ場・水族館（マリンラン ド）。スポーツランドが立地しており，いずれも近 鉄系列による経営である。

奥志摩地域における交通機関の整備は，宿泊施設 の整備より遅れ，バス輸送が主体である状態が続い たが，1970（昭和 45 ) 年の近鉄鳥羽線。志摩線の 開通 ${ }^{4)}$ により一新され，大阪・京都・名古屋との間 に直通特急電車が頻繁に運転されるようになった。 路線バスルートも再編が行なわれ，阿児町鵜方駅前 を中心に，奥志摩各地への路線が運行されている。 海上の船舶による観光ルートの整備も進み，遊覧船 。フェリ一航路が開設されている。今日，わが国の 主要な観光地である国鉄の周遊指定地における交通 機関の経営には，大手私鉄資本の参入が顕著な傾向 としてみられるが，奥志摩地域は近鉄による典型的 な交通機関の独占支配地域である(淡野明彦, 1978)。

\section{3。地域的インパクト}

\section{1) 雇用}

奥志摩地域の産業 (三区分) 別就業人口について みると（表 2 )，全般的な傾向として三重県平均に 比して第一次産業に占める比率が高く, 第二次産業 において低い。雇用源となる事業所について，産業 （大分類）別従業者数をみると（表 3 ），製造業に 占める比率が奥志摩地域では南島町を除いては県平 均を下回っており，工業の後進地域であることがわ かる。阿児町・浜島町・磯部町では製造業の比率が きわめて低く，逆にこれらの町ではサービス業の比 率が高い。観光開発の影響が反映しているものとみ ることができる。観光にかかわる業種は宿泊・娛楽 施設業を主体に，関連するものとして，運輸業，旅 行斡旋業, 飲食店, みやげ物店などの商業, マッサ ージ。芸妓などのサービス業にまで広汎に及ぶが， 本稿では主体である宿泊。娛楽施設業のみを観光業 種として限定しておく。阿児。浜島・磯部各町の宿 泊。娛楽施設業の従業者数について産業小分類別に みると（表 4 ), 各町ともサービス業従業者の 40 \%以上が旅館従業者によって占められており，また 阿児町ではゴルフ場等の娛楽施設の立地の結果とし て，運動競技場に分類される従業者の比率に特色が みられる ${ }^{5)}$ 浜島町ではサービス業従業者に占める観 光業種従業者の比率が $73.8 \%$ ，阿児町では $57.0 \%$ 之 なり, 観光開発は工業の後進地において大きな雇用 源となっている。このような観光業種による雇用が， どのような労働者層と結びついているかを考察する ために，阿児町・浜島町の政府登録ホテル，日観連 加盟旅館および観光客対象の娛楽施設について, 従 業者の性別・年令別・雇用形態別構成を調査した ${ }^{6)}$

（図 $5 ， 6$ ）。阿児町ではこれらの施設に 1,085 名 が従業しており，観光開発の主体となった近鉄系列

表 1 奥志摩地域の町別宿泊施設数

\begin{tabular}{|c|c|c|c|c|c|c|c|c|}
\hline \multirow{2}{*}{ 町別種別 } & \multicolumn{2}{|c|}{ 政府登録ホテル } & \multicolumn{2}{|c|}{ 日観連加盟旅館 } & \multicolumn{2}{|c|}{ 民 宿 } & \multirow{2}{*}{ 悉 } & \multirow{2}{*}{$\frac{\text { の他 } ※}{\text { 收容人数 }}$} \\
\hline & 数 & 室数 & 数 & 室数 & 数 & 収容人数 & & \\
\hline 町 & 1 & 200 & 13 & 348 & 28 & 811 & 1 & 210 \\
\hline 志摩町 & - & - & 2 & 35 & 83 & 2397 & 1 & 101 \\
\hline 浜島町 & 一 & - & 13 & 364 & 26 & 613 & 一 & - \\
\hline 大王町 & 一 & - & 2 & 40 & 29 & 810 & 一 & 一 \\
\hline 磯部町 & 一 & - & 8 & 181 & 6 & 140 & 一 & - \\
\hline 南勢田丁 & - & - & 2 & 28 & 27 & 724 & 1 & 120 \\
\hline 南島町 & - & - & - & - & 12 & 247 & 一 & - \\
\hline
\end{tabular}

※ュースホステル、保養センター、国民宿舎

（資料 ) 三重県生活環境観光公園課 
表 2 奥志摩地域の町別産業 (三部門) 別就業人口の比率

\begin{tabular}{l|rrrrrrrrr} 
& 三重目 & 阿児町 & 志摩町 & 浜島町 & 大王町 & 磯部町 & 南勢町 & 南島町 & 域内計 \\
\hline 就業人口数 & 782,827 & 8,589 & 7,658 & 3,512 & 4,705 & 4,871 & 6,342 & 4,887 & 40,564 \\
第二次産業比率 & 16.7 & 27.4 & 34.3 & 29.8 & 21.2 & 32.8 & 38.7 & 37.4 & 31.8 \\
第三次産業比率 & 36.9 & 21.6 & 28.7 & 20.4 & 39.6 & 23.3 & 30.7 & 30.7 & 276 \\
第三次産業比率 & 46.4 & 51.0 & 37.0 & 49.8 & 39.1 & 43.9 & 30.6 & 32.0 & 406
\end{tabular}

(資料) 昭和 50 年国勢調査

表 3 奥志摩地域の町別産業 (大分類) 別従業者の比率

\begin{tabular}{|c|c|c|c|c|c|c|c|c|}
\hline 業種】町別 & 三重県 & 阿児町 & 志摩町 & 浜島町 & 大王町 & 磯部町 & 南勢田丁 & 南島町 \\
\hline 農林水産業 & 0.8 & 0.5 & 5.6 & 0.7 & 1.7 & 4.0 & 18.9 & $1 . \approx$ \\
\hline & 0.3 & 0 & 0 & 0 & 0 & 0 & 0 & 1.5 \\
\hline 建 設 業 & 9.9 & 10.1 & 11.7 & 11.1 & 22.8 & 19.7 & 12.3 & 14.5 \\
\hline 製造 業 & 32.1 & 10.4 & 25.0 & 14.7 & 25.7 & 14.9 & 22.0 & 32.5 \\
\hline 卸売小売業 & 24.4 & 27.0 & 22.1 & 22.5 & 25.1 & 22.3 & 16.1 & 17.6 \\
\hline 金融保険業 & 2.5 & 2.4 & 2.3 & 1.4 & 0.4 & 0.4 & 0.8 & 0.9 \\
\hline 不動産業 & 0.5 & 0.5 & 0.3 & 0 & 0.2 & 0.1 & 0.5 & 4.5 \\
\hline 運輸通信業 & 6.0 & 7.6 & 3.2 & 3.1 & 2.5 & 5.6 & 3.5 & 0.1 \\
\hline ※供給業 & 0.7 & 0.8 & 0.3 & 0.3 & 0.2 & 0.7 & 0.2 & 0.1 \\
\hline サービス業 & 19.2 & 38.4 & 26.4 & 43.3 & 18.3 & 29.2 & 23.2 & 24.4 \\
\hline 公 & 3.5 & 2.2 & 3.1 & 2.8 & 3.1 & 3.1 & 2.7 & $3 . \varepsilon$ \\
\hline
\end{tabular}

※供給業一電気・水道・ガス・熱供給業

表 4. 産業 (小分類) 別従業者比率

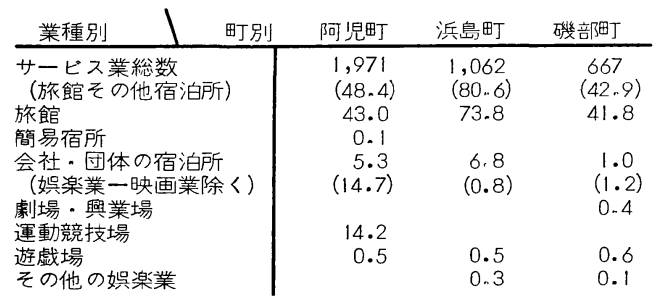

(資料) 昭和53年事業所統計調査結果 (未公表分)

には 868 名を数えっこれは町内 で発生する雇用の $34.0 \%$ に当たる。浜島町では 713 名で, ヤマ八系列 による雇用は $28.6 \%$ と低く,むしろ, 小規模な地元 資本の旅館の従業者が主体である。阿児・浜島両町 について共通する傾向としては，女子の中年層の雇 用が多く, パート雇用 (季節雇, 時間雇) の率が高 い。常勤の従業者数では男女ほぼ同じ割合であるか ら，地元の中年層の主婦が季節的”時間的波動に対 応する要員として雇用されていることがわかる。近 鉄・ヤマハの大手系列では，20２9才までの若年 層にも雇用が拡がっており，近鉄系列では全従業者 の $26.6 \%$ ，ヤマ八系列では $33.3 \%$ を占めている。非 大手系列ではその率は低く，阿児町で $12.9 \%$ ，浜島 町で $12.4 \%$ とどまっている。大手系列のホテル， 旅館では欧米風のサービス方式を採用寸る施設が多 く,このためフロント・レストラン部門等で若年労
（資料）昭和 53 年事業所統計調査報告書

働力を必要とするのに対し, 非大手系列では伝統的 な和風のサービス方式を維持するため, 中年層の女 子を必要とすることに, 両者の若年労働力の雇用の 差の一因を考えることができよう。人口流出の主体 となる新規卒業者と観光業種の結びつきをみる一方 法として, 奥志摩地域の中心校である県立志摩高 校 $^{7)}$ の最近 3 力年の卒業生の就職動向をみた(表5 )。 県外一の就職者と県内一の就職者はほぼ折半するが, 地元への就職者は就職者総数の $1 / 4$ 弱であり, 高卒 後の地元への定着者は少ない。地元での就職者の業 種別をみると，観光業種への就職が最も多く $1 / 3$ 強を占め，特に大手系列への就職が多い。近鉄・ヤ マハ系列は毎年就職者総数の約 $7 \%$ の雇用源となっ ているが，その主体は女子である。外来の大手資本 による観光開発は, 雇用源の少ない奥志摩地域にあ っては, 地元の若年労㗢力を吸収する主要な雇用源 としてみなせるが，その雇用力は微弱なもので, 加え て男子の雇用が少ないため, 若年労働力の域外一の 流出を阻止するほどの効果はあらわれていないとみ ることができる。むしろ，地域住民の雇用への観光 開発による効果としては，中年層の女子の雇用の桩 大につながったとみるべきであろう。このことは， 観光開発が宿泊・娛楽施設の立地を中心として展開 される以上，その業務内容の性格からみて，女子の 

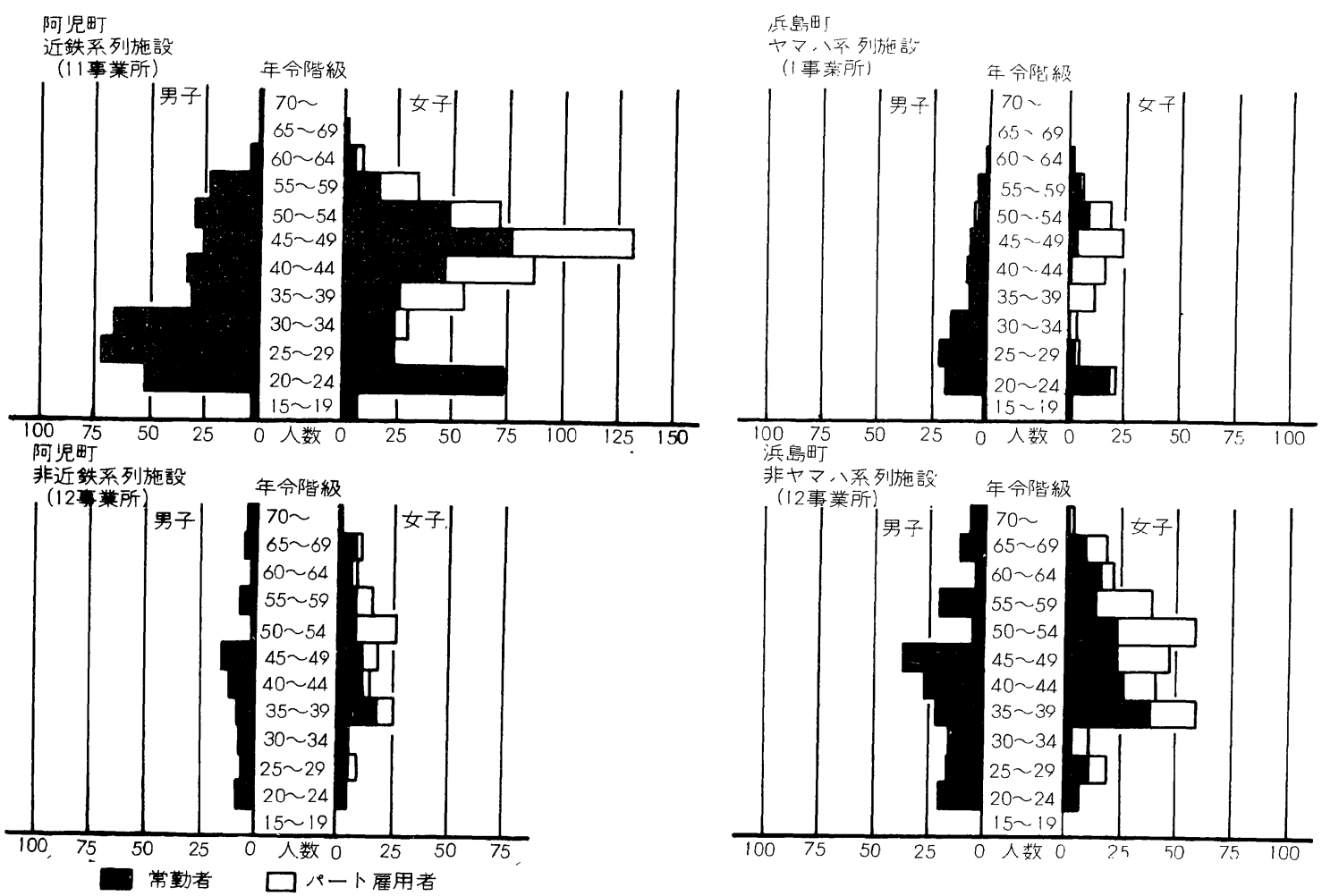

図 5 阿児町の観光種従業者の性別および年令別構成 （筆者のアンケート調查）

図 6 浜島町の観光業種従業者の性別および年 令別構成 (筆者のアンケート調査)

表 5 志摩高校における最近三力年の就職動向

\begin{tabular}{|c|c|c|c|c|}
\hline 区分 卒業年度 & 1977年度 & 1978年度 & 1979年度 & 三ケ年合計 \\
\hline 業者総数 & $345(215)$ & $337(206)$ & $327(210)$ & $1,009(631)$ \\
\hline 就職者総数 & $192(120)$ & $219 \quad(130)$ & $220(148)$ & $631 \quad(398)$ \\
\hline 県外就職者数 & $96(56)$ & $107(60)$ & 119 & $322(199)$ \\
\hline 県内就職者数 & 96 (64) & 112 & 101 & $309 \quad(199)$ \\
\hline うち奥志摩地域 & $44(32)$ & ( 35$)$ & 35) & $142(102)$ \\
\hline （観光業種） & $16(12)$ & ( 14) & 14) & 40) \\
\hline 近鉄。ヤマ & $15(12)$ & $16(12)$ & $14(9)$ & $45(33)$ \\
\hline
\end{tabular}

※（）内の数は女子（資料）三重県立志摩高等学校進路指導部

単純労務を多く必要とし，観光客の季節的・時間的 波動に合理的に対応できるパート雇用を取り入れる ため，若年労働力の安定した雇用源になりえにくい のではないかということを示しているものと推察で きる。

\section{2 ) 所得}

1977 (昭和 52 ) 年における, 三重県の雇用者所 得の人口 1 人当たり平均額は 85.9 万円で, 表 6 にみ られるように市町村間に大きな差があり，工業開発 の進んだ伊勢湾西岸臨海地域 (三重郡朝日町。川越
表 6 雇用所得人口一人当たり平均額 (1977年)

\begin{tabular}{|c|c|c|}
\hline 平均額 & 市町村数 & 備考 \\
\hline 140万円〜 & 1 & \\
\hline 130 & 0 & \\
\hline 120 & 2 & \\
\hline 110 & 3 & 113e8南勢田T \\
\hline 100 & 3 & \\
\hline 90 & 6 & \\
\hline 80 & 8 & 86.5 浜島町、81.2磯部町 \\
\hline 70 & 8 & 7\% 。5阿巟町 \\
\hline 60 & 13 & 68.1 大王町、65.2志摩町 \\
\hline 50 & 12 & 54.3南島町 \\
\hline 40 & 12 & \\
\hline 30 & 1 & \\
\hline
\end{tabular}

（資料）三重県統計課 : 昭和52年度地域別にみた県民所得 
町, 四日市市), 度会郡御薗町, 南牟婁郡鵜殿村や, 水産業の発達した度会郡紀勢町・南勢町, 尾熟市で 100 万円を越す高い額を示している。奥志摩地域の 各町についてみると, 南勢町を除いては, 浜島町・ 磯部町・阿児町の県平均水準を示す町と，大王町・ 志摩町。南島町の県内で低水準を示寸町とに二分さ れる。産業分類別の雇用者所得が公表されていない ので，雇用者所得に影響を与える純生産によって産 業分類別の比率を各町別にみると（表 7 )，南勢町 では水産業が卓越しており，阿児町・浜島町ではサ 一ビス業が高く,この両町では観光開発の影響が純 生産におけるサービス業の比重を高めているものと 考えられる。観光開発による地域住民一の所得への 効果をみるため, 公表資料 ${ }^{9}$ とアンケート調查の結
果をもとに産業分類別の所得の推計を試みた(表8)。 賃金・俸給 ${ }^{10)}$ に占めるサービス業の比率をみると, 阿児町・浜島町で $30 \%$ を上回っている。宿泊・娛楽 施設の観光業種分についてみると，阿児町・浜島町 ともに約 10 億円に達し,他の町との間に大きな差が あり，阿児町では賃金・俸給に占める比率は $8.5 \%$ ， サービス業に占める比率は $21.7 \%$ で, 同様に浜島町 では $16.1 \% ， 43.3 \%$ あるる。大手系列分について みると，阿児町では近鉄系列から 9.76 億円（宿泊・ 観光施設分の $85.3 \%$ ), 浜島町ではヤマ八系列から 1.38 億円 (宿泊・観光施設分の $14.9 \%$ ) である。 阿児町・浜島町では，観光業種における中年層の女 子への雇用の拡大が, 雇用者所得の上積み要因とな っているといえよう。ところが, 両町の雇用者所得

\section{表 7 奥志摩地域の町別産業 (大分類) 別純生産の比率 (1977年)}

\begin{tabular}{|c|c|c|c|c|c|c|c|c|}
\hline 産業別 | 町只 & 三重県 & 阿担町 & 志摩町 & 浜島田丁 & 大王町 & 磯部町 & 南勢田丁 & 南身 \\
\hline 第一次産業 & 7.0 & 11.5 & 27.2 & 26.2 & 18.1 & 12.7 & 48.4 & 47.8 \\
\hline 農 業 & 3.5 & 3. & 1. & 2 & 1. & 6 & 5.3 & 2.0 \\
\hline 林業 & 1.1 & 0.2 & 0.1 & 0.7 & 0. & 1.4 & 2.3 & 3.6 \\
\hline 水産業 & 2.4 & 8.0 & 26.0 & 23.1 & 16.0 & 5.3 & 40.9 & 42.2 \\
\hline 第二次産業 & 43.1 & 19.2 & 24.5 & 18.8 & 47.6 & 31.0 & 20.7 & 26.5 \\
\hline 鉱 業 & 0.3 & 0 & 0 & 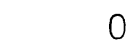 & - & 0.1 & 0 & 2.9 \\
\hline 建設業 & 11.3 & 13.0 & 15.1 & 12.9 & 34.3 & 21.9 & 13.3 & 12.9 \\
\hline 製造業 & 31.5 & 6.2 & 9.4 & 5.9 & 13.3 & 9.1 & 7.4 & 10.7 \\
\hline 第三次産 業 & 51.6 & 70.4 & 50.0 & 56.5 & 36.6 & 57.7 & 33.2 & 28.2 \\
\hline 卸売小売業 & 15.1 & 10.4 & 7.9 & 6.6 & 5.6 & 9.3 & 4.2 & 3.1 \\
\hline ※金融他業 & 7.6 & 8.3 & 7.0 & 3.4 & 1.9 & 1.1 & 2.9 & 2.0 \\
\hline 運輸通信業 & 5.6 & 3.2 & 3.5 & 3.3 & 2.6 & 15.0 & 3.9 & 2.9 \\
\hline ※供給業 & 2.1 & 1.3 & 0.3 & 0.6 & 0.5 & 2.3 & 0.0 & 0.0 \\
\hline サービス業 & 17.6 & 39.2 & 25.8 & 39.6 & 22.0 & 26.8 & 19.6 & 17.1 \\
\hline 公 務 & 3.5 & 3.0 & 5.5 & 3.0 & 4.4 & 3.2 & 2.6 & 2.7 \\
\hline 純生産額 & $, 054,944$ & 18,426 & 11,616 & 8,729 & 7,492 & 10,924 & 14,207 & 1,312 \\
\hline
\end{tabular}

（純生産額の単位 : 百万円）※金融他業一金融・保険・不動産業 供給業一電気・水道・ガス・熱供給業 (資料) 三重県統計課：市町村別純生産

表 8 奥志摩地域の町別産業別雇用者所得の推計（1977年）（\%）賃金・俸給に対する比率

\begin{tabular}{|c|c|c|c|c|c|c|c|}
\hline 町別 & 阿児町 & 志摩町 & 浜島町 & 大王町 & 磯部町 & 南勢町 & 南島町 \\
\hline 雇用者所得 & $\begin{array}{r}14,878 \\
70.5\end{array}$ & $\begin{array}{r}10,885 \\
65.2\end{array}$ & & & & & \\
\hline 賃金。俸給 & 13,510 & 9,884 & 5,768 & 6,249 & 7,3 & 14 & 6,361 \\
\hline 第三次産業分 & 8, & 2 & & & & & \\
\hline サービス業分 & $\begin{array}{r}58.4 \\
5,282\end{array}$ & 1,738 & 2,144 & 876 & 1,896 & 1,676 & 1,212 \\
\hline$(\%)$ & 35.5 & 16.0 & 33,8 & 12.7 & 23.6 & 10.8 & 19.1 \\
\hline 宿泊。観光斿 & 1,144 & 70 & 929 & 90 & 282 & 66 & 42 \\
\hline$(\%)$ & 8.5 & 0.7 & 16.1 & 1.4 & 3.9 & 0.5 & 0.7 \\
\hline
\end{tabular}

单位 : 百万円 (顧用者所得一人当りのみ一万円 ) 
の一人あたり平均額が県平均水準にとどまっている のは，産業別労働者の平均現金給与額における宿泊 施設業労働者の相対的低水準，および女子のパート 雇用率の高さなどが考えられる。

\section{3) 財政}

観光開発に伴う地方自治体一の税収としては, 施 設の立地による法人住民税・法人事業税・固定資産 税, 観光客に直接賦課される料理飲食等消費税 - 娛 楽施設利用税。入場税がある。市町村税としては市 町村民税（個人分・法人分），固定資産税および 入湯税である。市町村税の内訳をみると，上記の 3 税目に加え, 軽自動車税, たばこ消費税, 電気・ガ ス税，特別土地保有税があり，その中心は市町村民 税と固定資産税である。市町村の歳入における市町 村税の占める比率は, 市町村の財政基盤の強弱を示 寸指標であるが，いま1977（昭和 52 )年の三重県 内各市町村における市町村税の比率を求めると（表 9 ）。平均は $19.5 \%$ である。高率を示す市町村とし ては三重郡朝日町 $(54.3 \%)$, 四日市市 ( $45.3 \%)$, 三重郡川越町 $(40.1 \%)$, 鈴鹿市 $(37.0 \%)$ の伊 勢湾西岸臨海地域々度会郡御薗村 $(41.9 \%)$ ) ずれも工業開発の進んだ市町村である。奥志摩地域 の各町についてみると, 阿児町と浜島町とで県平均 を上回る比率がみられ。他の町では平均以下である。 奥志摩地域外の観光地である三重郡菰野町 (湯/山 温泉），桑名郡長島町（長島温泉）でも高い比率が (30.6\%,31.8\%)みられることから,観光開発の結果が税 収の増加へと導いていることが推察できる。人口 1 人当たりの市町村税収入額をみても(表 10$)$, 県平 均が 3.2 万円であるのに対し, 四日市市 ( 6.7 万円), 三重郡朝日町 ( 6.8 万円), 同川越町 ( 5.0 万円) などの工業地域で高い值がみられ，奥志摩地域では

表 9 市町村歳入に占める市町村税の比率 (1977年)

\begin{tabular}{l|r|l} 
比率 & 市町村数 & 備考 \\
\hline $50 \sim 54 \%$ & 1 & \\
$45 \sim 49$ & 1 & \\
$40 \sim 44$ & 2 & \\
$35 \sim 39$ & 1 & \\
$30 \sim 34$ & 7 & 阿児町 \\
$25 \sim 29$ & 6 & \\
$20 \sim 24$ & 13 & 浜島町 \\
$15 \sim 19$ & 12 & 志摩町、大王町、南勢町 \\
$10 \sim 14$ & 16 & 磯部町 \\
$5 \sim 9$ & 9 & 南島町 \\
$\sim 4$ & 1 &
\end{tabular}

(資料) 昭和52年三重県統計書
阿児町（ 3.3 万円）, 浜島町 ( 4.8 万円) 以外は平均 を下回っている。三重郡菰野町, 桑名郡長島町 では平均以上の值（ 5.5 万円， 4.9 万円）とな っており，市町村税の比率と同様の傾向を示してい る。税目毎に阿児町・浜島町についてみると，阿児 町では法人分町民税の $17.5 \%$, 固定資産税の $8.8 \%$ が観光業種からによるもので，町税収入の $5.7 \%$ を 占める。浜島町では法人分町民税の $12.3 \%$, 固定資 産税の $31.2 \%$ が観光業種からで，町税収入の 8.8 \%を占める (図 7 )。税額としては両町ともほぼ同 じであるが (阿児町 345 百万円, 浜島町 319 百万円)。 阿児町の財政規模が浜島町に比し大きいため，町税 比率への反映はやや低い。両町では観光開発の結果 が税収の増加へと寄与し, 奥志摩地域の他の町と の間に歳入面での差をつけているとみなせる。両町 における大手系列からの税収についてみると，阿児 町では近鉄系列から観光業種による税収の $83.3 \%$, 浜島町では同様にヤマ八系列から $68.5 \%$ で, その比 重の大きさをみることができ，ことに浜島町におけ るヤマハ系列が雇用・所得面では地元の小資本に劣 っていたのに対し，税収面では広大な面積を占める ため，寄与の度合いが高い。特別土地保有税 ${ }^{12)}$ 観 光開発に伴う波及効果としてとらえると，阿児町で は町税収入の $7.1 \%$, 浜島町では $33.2 \%$ で, 観光業 種加らの法人分町民税“固定資産税に加えると，阿 児町では町税収入の $12.8 \%$ ，浜島町では $42.3 \%$ に 達する。観光開発が税収の増加として財政の歳入面 をうるおすが，観光開発に伴う道路等の新設。改良 工事により歳出面での町当局の負担増が考えられ， 歳出面での検討をも加えなければならないが，観光

\section{表 10 市町村人口一人当たりの市町村税収額}

\begin{tabular}{|c|c|c|}
\hline 税収額 & 市町村数 & 備考（1977年） \\
\hline 6.5 万田 & 2 & \\
\hline $6.0 \sim 6.4$ & 0 & \\
\hline $5.5 \sim 5.9$ & 1 & \\
\hline $5.0 \sim 5.4$ & 2 & \\
\hline $4.5 \sim 4.9$ & 3 & 浜島町 \\
\hline $4.0 \sim 4.4$ & 10 & \\
\hline $3.5 \sim 3.9$ & 5 & \\
\hline $3.0 \sim 3.4$ & 8 & 阿児町 \\
\hline $2.5 \sim 2.9$ & 16 & 南勢町、磯部町 \\
\hline $2.0 \sim 2.4$ & 10 & 大王町 \\
\hline $1.5 \sim 1.9$ & 12 & 志摩町、南島町 \\
\hline
\end{tabular}

(資料) 昭和 52 年三重県統計局 


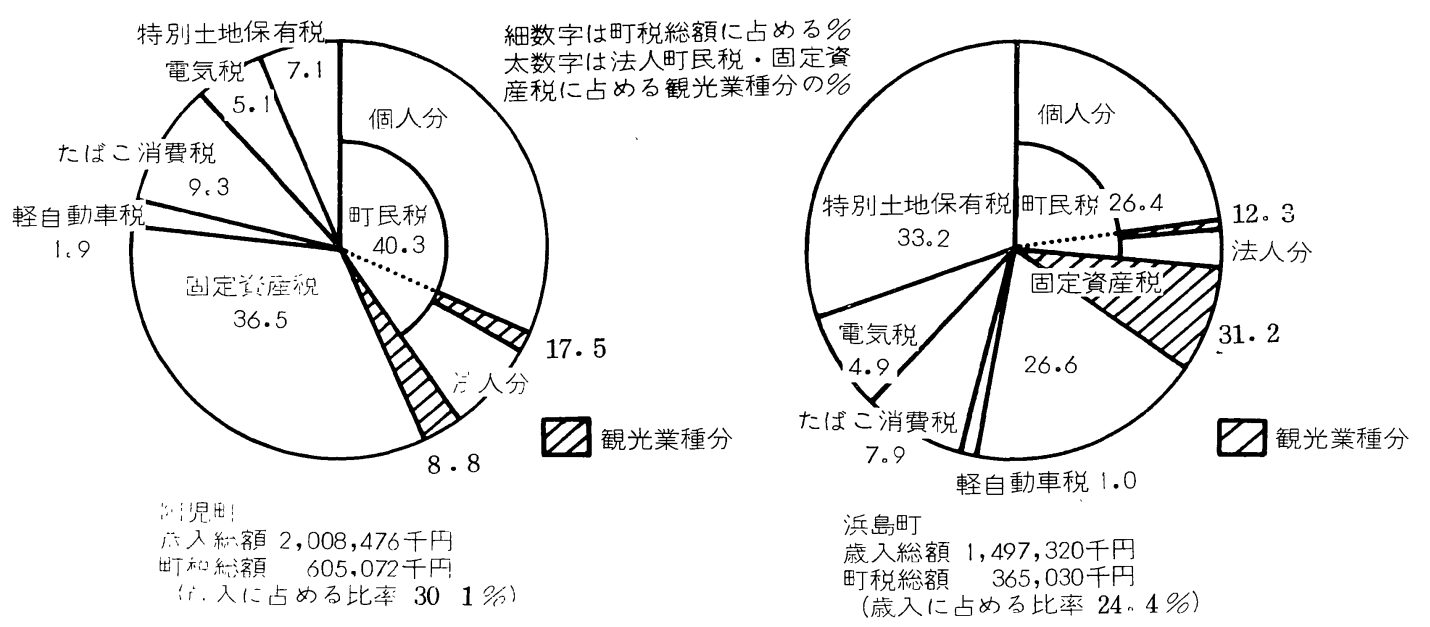

(資料) 各町税務課

図 7 阿児町・浜島町における町税に占める観光業種からの税収 (1977年)

関連と非関連の歳出のふるい分けが容易でないため, 本稿では歳入面だけの考察とした。

\section{4。まとめ}

観光開発による地域的インパクトを，市町村レベ ルで雇用・所得・財政の面から, 伊勢志摩国立公園 域の奥志摩地域を事例として考察したところ，次の ことが明らかとなった。

(1)観光開発は, 当該地域での雇用機会の増大につ ながり，雇用源の少なかった地域において主要な雇 用源となっている。しかし，女子の中年層の雇用が 多く, 雇用形態としてパート雇用の率が高いため, 人口流出の主体となる若年労働力の雇用源としては, 流出を阻止するほどの効果は現段階ではみられない。

(2)観光開発による雇用機会の増大は, 当該地域の 雇用者所得を押し上げる要因となっている。しかし， 女子の雇用の多さ・パート雇用の採用および観光業 種における他業種に比しての賃金水準の低さが，雇 用者所得の押し上げにブレーキをかけている。

(3)観光開発は, 財政の歳入面での税収の増加に効 果をもち，財政基盤の強化に寄与している。

(4)大手資本による観光開発は，規模が大きいため, 雇用・所得・財政面への即効的な効果をみせている。

公表資料”行政の内部資料およびアンケート調査 によって，一応本稿の目的を果すことができたが， 観光開発による雇用。所得”財政面以外の波及効果 についての考察も機会をみて行いたい。

本稿は 1980 年日本地理学会春季学術大会で発表 した内容をもとに，その後資料の補正・追加を行っ
たものである。研究に際しご協力をいただいた三重 県庁, 阿児町役場, 浜島町役場および近鉄系企業の 関係者各位に厚く御礼申し上げます。

\section{参考文献}

菊地一郎・淡野明彦 (1979)：伊勢志摩における観 光開発の展開と経済的効果, 奈良教育大学紀要,

$28-1$ (人文。社会科学 ). pp. 101 117 淡野明彦 (1974) : 私鉄資本の進出に伴う秩父地方 の変容, 地理学評論 $47-8$, pp. 498 510 淡野明彦 (1978)：日本の主要観光地における大手 私鉄資本進出の実態，新地理 $25-4, \mathrm{pp} \cdot 29 \sim 5 \varepsilon$ 浜口 誠 $(1975)$ : 観光と開発 一 伊勢志摩国立公 園の実態 一, 「三重県の地理」第 5 章第 1 節。 浜口 誠 $(1976)$ : 伊勢志摩, 「日本地誌」 13 ： pp. 349 367, 二宮書店。

注

1) 三重県志摩郡全域 ( 阿児町, 大王町, 浜島町, 志摩町, 磯部町) と度会郡南勢町, 南島町の総称 として用いた。

2） 1927 (昭和 2 ) 年に設立されたが, 1944 （昭 和 19 ) 年に鳥羽湾交通を合併し,社名を志摩航運 と改称した。1948（昭和 23 ）年に株式取得によ り近鉄傘下に入り, 現在は近鉄志摩観光船となっ ている。

3）民宿という名称は定義されたものではないが， 通常, 料理飲食等消費税の免税点内の基本宿泊料 金で営業を行なう旅館に対して呼ばれる名称であ る。

4) 近鉄鳥羽線（宇治山田一鳥羽間）は新設路線で 
あるが，志摩線は $1929 （$ 昭和 4）年に開通した 志摩電気鉄道の路線を改軌・D部路線の変更を行 ったものである。

5）合歓の郷にも娛楽施設があるが，宿泊施設の従 業者との分離が困難なため，宿泊施設にすべて含 めた。

6) 阿児町では対象施設は 23 力所( うち未調查 3 力所), 浜島町では 13 力所 ( うち末調查 2 力所), である。

7）奥志摩地域には，この他に県立志摩水産高校が あるが生徒数は少なく, 奥志摩地域から輩出する 新規就職者の主体は志摩高校であるという。

8）しかし, 就職後の定着率は悪く, 結婚等で短期 間で退職する者が多いという。すなわち, 毎年の 就職者が年を追って累積されるわけではない。

9) 三重県企画調整部統計課「毎月勤労統計調査」 を金額算定の基本資料とした。従業者数について は, 昭和 50 年および昭和 53 年事業所統計調查を 基本資料とした。

10) 雇用者所得から, 社会保障雇主負担・その他の 雇主負担を差し引いたものである。

11）昭和 52 年における三重県産業別および性別 常
用労働者の 1 人当り平均月間現金給与額を主要産 業についてみると別表の通りとなる。

\begin{tabular}{|c|c|c|c|c|c|c|}
\hline 産業別 & 製造業 & $\begin{array}{l}\text { (単位： } \\
\text { 卸売 · } \\
\text { 小売業 }\end{array}$ & $\begin{array}{l}\text { 千円) } \\
\text { 金融 - } \\
\text { 保険業 }\end{array}$ & $\begin{array}{l}\text { 運輸 } \cdot \\
\text { 通信業 }\end{array}$ & $\begin{array}{c}\text { サービス } \\
\text { 業 }\end{array}$ & $\begin{array}{l}\text { (旅館その } \\
\text { 他宿泊所) } \\
\end{array}$ \\
\hline $\begin{array}{l}\text { 給与額 } \\
\text { (男子) }\end{array}$ & 221 & 206 & 335 & 231 & 262 & 170 \\
\hline $\begin{array}{l}\text { 給与額 } \\
\text { (女子) }\end{array}$ & 98 & 92 & 184 & 184 & 185 & 103 \\
\hline
\end{tabular}

（資料）毎月勤労統計調査地方調査年報

12）昭和 48 年度の税制改正において創設されたも ので，土地讓渡に伴う投機的な取引を抑制し，あ わせて土地の供給促進を図る目的で，土地の取得 と保有に対して課せられる。観光開発の盛んな地 域では, 将来の地価の高騰をみこしての土地の先 行取得や，主に大手資本による大規模開発のためめ の買い占めが行われるため。一つの波及効果とみ ることができる。

(たんの あきひこ=奈良教育大学 専任講師 $)$

\section{The Impacts of Expantion of the Tourism Industry on Areal Economy:}

A Case Study of Okushima Area in Mie Pref.

TANNO, akihiko

In Japan, recently activities of tourism have been growing rapidly. In the economically underdeveloped districts, the expansion of tourism industry is expected as a hopeful prospect for promoting the development of areal economy.

This paper is aimed at analysis of the impact of the expantion of tourism industry on areal economy through the case of the Okushima area (the southern part of the Ise-Shima area) where is well-known as prominent tourist resort.

The results of this study can be found in the following passage.

(1) The location of tourism industry effects increase in employment mostly of middle-aged women. So, the tourism industry development has few effect against the outflow of young-aged person.

(2) The increase in employment by tourism industry is an important factor of rising in the employee's income.

(3) The tax paying from tourism industry contributes to increasing of revenue of local autonomous entities. 